\title{
Application of Reclaimed Wastewater in the Irrigation of Rosebushes
}

\author{
Luccas Erickson de Oliveira Marinho • Adriano Luiz Tonetti • \\ Ronaldo Stefanutti • Bruno Coraucci Filho
}

Received: 25 March 2013 / Accepted: 23 July 2013 / Published online: 10 August 2013

(C) The Author(s) 2013. This article is published with open access at Springerlink.com

\begin{abstract}
The use of reclaimed wastewater in agriculture can be a solution for regions with water shortages or low rainfall periods; besides fulfilling the crop's water needs, it would also promote the recycle of nutrients. However, care should be taken regarding soil salinization, especially in closed environments such as greenhouses for the cultivation of ornamental plants. The domestic effluents are rich in sodium which can accumulate on soil and cause soil sealing. This study evaluated the use of effluents from anaerobic filters and intermittent sand filters in the production of rosebushes (Rosa hybrida "Ambiance"). The crop yield of the rosebushes irrigated with reclaimed wastewater exceeded the one obtained with traditional cultivation, reaching a value $31.8 \%$ higher when employing nitrified effluent originated from intermittent sand filters, with no difference in the product quality. The salinity levels are below the critical limits found in the literature; however, there was a significant increase compared to the irrigation with drinking water.
\end{abstract}

Keywords Effluent · Fertigation · Nutrients · Roses · Ornamental plants

L. E. d. O. Marinho • A. L. Tonetti $(\bowtie) \cdot$ B. Coraucci Filho School of Civil Engineering, Architecture and Urbanism, FEC/UNICAMP, Avenida Albert Einstein, 951,

Cidade Universitária “Zeferino Vaz”, P.O. Box 6021, 13083-852 Campinas, SP, Brazil

e-mail: ADRIANO@FEC.UNICAMP.BR

R. Stefanutti

Center for Technology, Federal University of Ceará,

UFC, Benfica Fortaleza, Brazil

\section{Introduction}

In Brazil, the production of flowers and ornamental plants has expanded considerably, with record-breaking exports of these products. The main production centers are located in the Brazilian Southeast, where there are serious water shortages, which can prevent the spread of this economic activity.

The irrigation technologies improvement and the unconventional water resources use would contribute to the maintenance of a satisfactory water supply for this high production level (de Paula et al. 2010; Hassanli et al. 2009). According to Monnet et al. (2002), for regions with water shortages or low rainfall, the use of treated sanitary effluents in agriculture can be a solution, besides fulfilling the crop's water requirements it would also promote the recycling of nutrients. The domestic wastewater contains loads of nitrogen and phosphorus, which can replace conventional fertilizers in vegetable cultivation.

Carr et al. (2004) estimated that $18 \%$ of the agricultural land is irrigated, producing $40 \%$ of the food consumed in the world. Of these, $10 \%$ has been irrigated with reclaimed wastewater. According to Nirit et al. (2006) in Israel, on 2010, it was expected that $45 \%$ of the water used to irrigate agricultural lands was from reclaimed wastewater. Besides, in that country, over $60 \%$ of the urban wastewater is reclaimed to be used in agriculture and it is expected that this value reach $100 \%$ by 2015 (Lavee 2010).

The use of reclaimed wastewater to irrigation of ornamental flowers has some advantages in comparison to other crop productions since its production is a high added-value activity with demands of great amount of 
water and nutrients. The water reuse on these plants allows the increase on nutrient and water recycling saving the high-quality water only for potable uses and reduces the effluent disposal in receiving water bodies (AlLahham et al. 2003; Coppola et al. 2004). Furthermore, as the ornamental plants usually are not used in the human feed, the requirements in the treatment of sewage is reduced, although the effect of reclaimed wastewater irrigation has to be carefully evaluated since some studies have shown diffuse damaging of ornamental plants and trees irrigated with reclaimed wastewater (Lubello et al. 2004). The drip irrigation system of reclaimed wastewater can both minimize the risks of contamination and provide water and nutrient direct on the plant root and it is the most appropriate irrigation system for this purpose (Freitas et al. 2012).

Reuse should be carefully evaluated to minimize the risk of environmental contamination, such as nitrate leaching into the underground aquifer. There is also high sodium concentrations present in domestic sewage that, when applied in the irrigation of agricultural crops, can cause soil sealing. Salinity problems have been observed in the irrigated systems of greenhouses producing ornamental plants, which are due to the natural rainfall interception by the greenhouse cover, and the inadequate management of both the soil and the irrigation.

The main objective of this paper was to evaluate the use of effluents generated in a wastewater treatment system for watering rosebushes by analyzing the productivity and quality of the flowers and the soil contamination by salinity and the sodium adsorption ratio (SAR).

\section{Materials and Methods}

This research was conducted in an experimental area located at the State University of Campinas for a period of 2 years. The raw sewage was collected at a location, in the university, with a daily traffic of about 10,000 people. Part of this wastewater was directed to four anaerobic filters constructed in stainless steel cylindrical vessel with a total volume of $500 \mathrm{~L}$ and operated with up-flow and hydraulic retention time of $9 \mathrm{~h}$. The support material used was composed of coconut shells from the Cocos nucifera species, which had each unit divided into four parts prior to its placement within the cylinder.
The effluent generated by these reactors followed two distinct paths in the experimental area: (a) half was directed to tanks for the rosebushes' irrigation (anaerobic effluent irrigation); (b) half was applied on the surfaces of four intermittent sand filters at the rate of $300 \mathrm{~L} \mathrm{~m}^{-2}$ day $^{-1}$ and in loads of $50 \mathrm{~L} \mathrm{~m}^{-2}$ evenly distributed throughout the day (nitrified effluent) for the subsequent irrigation of a different group of rosebushes.

Fiber glass cylindrical boxes with internal diameter of $1.00 \mathrm{~m}$ were used in the construction of the sand filters. The bed was composed by three stratified layers from the base of the reactor. The first was $0.20 \mathrm{~m}$ deep and consisted of gravel with effective size $\left(D_{10}\right)$ of $16.12 \mathrm{~mm}$ and uniformity coefficient (UC) of 1.88 . The second layer consisted of gravel with $\mathrm{D}_{10}$ equal to $7.51 \mathrm{~mm}$ and UC of 1.66 , and was $0.05 \mathrm{~m}$ deep. This material aimed to support the sand; thus, preventing the drainage of its particles (Tonetti et al. 2010).

The sand bed was $0.75 \mathrm{~m}$ deep and the sand used had effective size of $0.17 \mathrm{~mm}$ and uniformity coefficient of 3.14. After passing through the sand filter, the effluent showed a complete nitrification of the nitrogen compounds and it was transferred to tanks for the rosebushes' irrigation.

\subsection{Description of Planting the Rosebush}

The chosen culture was the Rosa hybrida "Ambiance" grafted on Natal-Bryan rootstock. The culture was transplanted into 24 beds measuring $2.70 \mathrm{~m}$ wide, $0.40 \mathrm{~m}$ high, and $2.70 \mathrm{~m}$ long. The rosebushes were spaced at $0.15 \mathrm{~m}$ with a total of 21 plants in each row. Each bed consisted of three rows spaced at $1.20 \mathrm{~m}$.

A bow-style greenhouse with transparent cover of low-density polyethylene was built for the rosebushes' protection. The greenhouse was $16.0 \mathrm{~m}$ wide, $36.0 \mathrm{~m}$ long, and $4.5 \mathrm{~m}$ maximum ceiling height for a total area of $576.0 \mathrm{~m}^{2}$.

The existing soil in the experimental area was classified as sandy clay with density equal to $1.3 \mathrm{~g} \mathrm{~cm}^{-3}$, field capacity of $26.13 \%$ moisture, and permanent wilting point of $17.18 \%$. The soil chemical analysis results led to the addition of dolomitic limestone to correct the $\mathrm{pH}$ acidity prior to the transplanting. The limestone was plowed to a depth of $0.20 \mathrm{~m}$.

Randomized blocks were used as the experimental delineation as shown in Table 1. Fertilization was applied at 30,75, and 110 days after the planting for 
Table 1 Summary of all water types used to irrigation and fertilization

\begin{tabular}{ll}
\hline Test & Number of beds \\
\hline T1-Clean water without fertilization & 4 \\
T2-Nitrified effluent with fertilization & 4 \\
T3-Anaerobic effluent with fertilization & 4 \\
T4-Anaerobic effluent without fertilization & 4 \\
T5-Nitrified effluent without fertilization & 4 \\
T6-Clean water with fertilization & 4 \\
\hline
\end{tabular}

the T2, T3, and T6 tests using NPK (10:10:10) and ammonium sulfate $\left(20 \mathrm{~kg} \mathrm{ha}^{-1}\right)$. This action sought to evaluate the need for topdressing while cultivating the rosebushes with the irrigation containing the effluent under study. Both the topdressing fertilizer and the planting fertilization followed the guidelines provided by Raij et al. (2008).

The clean water for the irrigation came from the municipal water supply. The anaerobic effluent from the anaerobic filters was used for the T3 and T4 tests. The effluent from the sand filters (nitrified effluent) was used for the $\mathrm{T} 2$ and $\mathrm{T} 5$ tests.

The start of the irrigation was determined by the crop's water requirements, based on the readings by the tensiometers installed in the central part of each bed at the depths of 0.10 and $0.30 \mathrm{~m}$. Irrigation was initialized at $-10 \mathrm{kPa}$ tension, as recommended by Casarini (2004), using $1.3 \mathrm{~mm}$ polyethylene drip tubes, providing a flow rate of $1 \mathrm{~L} \mathrm{~h}^{-1}$.

\subsection{Soil, Leachate, and Effluent Analysis}

Soil samples from each bed were collected and analyzed for organic matter, phosphorus, potassium, sodium, calcium, and magnesium contents. The collection was performed using a Dutch auger allowing the removal of soil samples at 15 different points on each bed at depths from 0.00 to $0.30 \mathrm{~m}$. The collected soils of all 15 points were property mixed and tested in a laboratory.

The leachate collection was made by a Lysimeters (soil solution extractor), which were installed in all beds at two different depths: 0.10 and $0.30 \mathrm{~m}$. For the sampling, a negative pressure was applied inside the extractor to remove the water for the appropriate analysis. Samples from both types of effluents (anaerobic effluent and nitrified effluent from the sand filters) were collected every time the irrigation system was turned on. All analyzes were performed according to Standard Methods for the Examination of Water and Wastewater (APHA, AWWA, WEF 2005).

\subsection{Evaluation of the Rose Yield}

The determination of the rosebushes productivity was performed by a sampling during the production period, which usually occurred 2 months after the beginning of the irrigation process. Straight stems measuring more than $30 \mathrm{~cm}$ and presenting a floral bud were considered as of commercial grade. The stems were classified in three different sizes of 30,40 , and $60 \mathrm{~cm}$; because of commercial wrapping, the flower stems should have the same length to make the bouquets.

The length of the stems was measured from the cutting point to the end of the bud. The stem diameter was determined at its lower end using a vernier caliper. As for the rose buds, the length was determined from the base of the bud, while the diameter was measured in its median part. Twenty harvests were performed throughout the experiment.

\section{Results and Discussion}

Table 2 shows the characterization of the effluent used to irrigate the rosebushes culture. The results reflect the evaluation of 25 samples from each of the sampling points and indicate that, as expected, the anaerobic effluent presented nitrogen predominantly in the organic and ammoniacal forms (total Kjeldahl nitrogen). In the effluent from the sand filters, there was a preponderance of nitrate-nitrogen, which represented $85.5 \%$ of the nitrogen compounds.

The anaerobic effluent had a SAR of $3.1 \mathrm{meq}^{0.5} \mathrm{~L}^{-0.5}$, while the nitrified reached $2.9 \mathrm{meq}^{0.5} \mathrm{~L}^{-0.5}$. By applying these results to the Ayres and Wescott (2008) water classification diagram, it was found that both effluents would be suitable for plants with good salt tolerance and unsuitable for soils with deficient drainage.

The culture used in this study, R. hybrida "Ambiance", has low tolerance for soil salinity; however, when evaluating the sodium concentration data shown in Table 2, it is noted that the value found in the effluents used in this study were lower than the limits set, by Crook (1991), for that compound. According to the cited author, when the sodium concentration is greater than $69 \mathrm{mg} \mathrm{L}^{-1}$, there is a 
Table 2 Characterization of anaerobic effluent and effluent from the sand filters (nitrified) used in the irrigation of the rosebushes

$T K N$ total Kjeldahl nitrogen, n.d. not detected

\begin{tabular}{lllll}
\hline Parameter & Unit & Anaerobic effluent & Nitrified effluent & Clean water \\
\hline $\mathrm{pH}$ & - & $6.8 \pm 0.2$ & $6.5 \pm 0.9$ & $7.1 \pm 1.0$ \\
$\mathrm{TKN}-\mathrm{N}$ & $\mathrm{mg} \mathrm{L}^{-1}$ & $49.2 \pm 9.0$ & $7.5 \pm 6.0$ & $0.9 \pm 1.0$ \\
Nitrate-N & $\mathrm{mg} \mathrm{L}^{-1}$ & $0.6 \pm 0.9$ & $44.1 \pm 22.0$ & $0.8 \pm 0.4$ \\
Nitrite-N & $\mathrm{mg} \mathrm{L}^{-1}$ & n.d. & n.d. & n.d. \\
Phosphorus & $\mathrm{mgL}^{-1}$ & $2.2 \pm 0.6$ & $1.7 \pm 0.6$ & n.d. \\
Sodium & $\mathrm{mg} \mathrm{L}^{-1}$ & $50.2 \pm 4.2$ & $56.0 \pm 3.5$ & $12.3 \pm 2.4$ \\
Potassium & $\mathrm{mg} \mathrm{L}^{-1}$ & $19.6 \pm 4.9$ & $107.0 \pm 8.3$ & n.d. \\
Calcium & $\mathrm{mg} \mathrm{L}^{-1}$ & $27.4 \pm 5.8$ & $31.3 \pm 5.6$ & n.d. \\
Magnesium & $\mathrm{mg} \mathrm{L}^{-1}$ & $5.0 \pm 3.4$ & $4.5 \pm 2.8$ & n.d. \\
SAR & $\mathrm{meq}^{0.5} \mathrm{~L}^{-0.5}$ & 3.1 & 2.9 & n.d. \\
\hline
\end{tabular}

contamination risk for the plant, which may promote excessive absorption, which is highly phytotoxic, particularly when the soil moisture is low.

Furthermore, the soil was classified as sandy clay, which presents no drainage deficiency, and with only a slight possibility of achieving dangerous levels of exchangeable sodium.

\subsection{Soil and Leachate Analysis}

As shown in Table 3, in all tests, there was no significant difference between the concentrations of organic matter. For phosphorus and potassium, as expected, lower results were found in the tests that did not receive topdressing (T1, T4, and T5). There was a trend of increasing available phosphorus in soil from tests irrigated with anaerobic effluent (T3 and T4) which possessed higher concentration of phosphorus (Table 2). It may be noted that in tests where there was a topdressing (T2, T3, and T6) the concentration of potassium in the soil was significantly higher than those found in other tests (T1, T4, and T5). The nitrified effluent irrigation (T5 and T2) did not result in a higher concentration of potassium in the soil. It should be noted that the nitrified effluent showed a higher concentration of potassium in their composition (Table 2). Thus, the action that caused greater interference in potassium concentration in the soil was the topdressing.

The leachate could not be assessed due to the impossibility of obtaining liquid samples from the extractor during the study. The efficient irrigation system adopted only provided the water content demanded by the culture. According to Cararo et al. (2006), drip irrigation also have the advantage of minimizing the direct contact of the liquid with the agricultural product; thus, hindering any possibility of contamination.

According to the data shown in Table 4, in relation to the initial soil conditions, the SAR showed an increase in all cases. The lowest value was found for the T1 test, which received no topdressing, and was irrigated with water. The highest SAR was obtained in the T5 test (nitrified effluent without fertilization), and it was significantly different from the T2, T3, T4, and T6 tests. According to Rengasamy and Olsson (1991), attention should be paid to the toxicity caused by SAR when its value is above $3.0 \mathrm{meq}^{0.5} \mathrm{~L}^{-0.5}$. Thus, despite the significant increase, the compromising SAR values have yet to be achieved; however, this parameter should be kept under constant review to prevent or remedy its impact to the soil.

Table 3 Concentration of organic matter, phosphorus and potassium in the soil

\begin{tabular}{llll}
\hline & $\begin{array}{l}\text { Organic matter } \\
\left(\mathrm{g} \mathrm{dm}^{-3}\right)\end{array}$ & $\begin{array}{l}\text { Phosphorus } \\
\left(\mathrm{mg} \mathrm{dm}^{-3}\right)\end{array}$ & $\begin{array}{l}\text { Potassium } \\
\left(\mathrm{mmol}_{\mathrm{c}} \mathrm{dm}^{-3}\right)\end{array}$ \\
\hline $\begin{array}{l}\text { Initial soil } \\
\text { condition }\end{array}$ & $16.0 \mathrm{a}$ & $1.0 \mathrm{a}$ & $0.4 \mathrm{a}$ \\
T1 & $20.5 \mathrm{~b}$ & $96.2 \mathrm{~b}$ & $4.8 \mathrm{~b}$ \\
T2 & $20.7 \mathrm{~b}$ & $299.7 \mathrm{~cd}$ & $14.4 \mathrm{bc}$ \\
T3 & $22.0 \mathrm{~b}$ & $456.0 \mathrm{~d}$ & $18.1 \mathrm{c}$ \\
T4 & $20.2 \mathrm{~b}$ & $174.2 \mathrm{c}$ & $3.2 \mathrm{~b}$ \\
T5 & $19.7 \mathrm{~b}$ & $112.7 \mathrm{~b}$ & $6.1 \mathrm{~b}$ \\
T6 & $18.5 \mathrm{~b}$ & $218.7 \mathrm{~cd}$ & $15.9 \mathrm{c}$ \\
\hline
\end{tabular}

Statistical analysis between values with different letters are statistically significant $(p<0.05)$ 
Table 4 Sodium adsorption ratio (SAR) and exchangeable sodium percentage (ESP)

\begin{tabular}{lcc}
\hline & SAR $\left(\mathrm{meq}^{0.5} \mathrm{~L}^{-0.5}\right)$ & ESP (\%) \\
\hline Initial soil condition & $<0.1 \mathrm{a}$ & $<0.1 \mathrm{a}$ \\
T1 & $0.5 \mathrm{~b}$ & $2.5 \mathrm{~b}$ \\
$\mathrm{~T} 2$ & $1.2 \mathrm{bc}$ & $5.2 \mathrm{c}$ \\
$\mathrm{T} 3$ & $1.2 \mathrm{c}$ & $5.0 \mathrm{~cd}$ \\
$\mathrm{~T} 4$ & $0.9 \mathrm{bc}$ & $4.6 \mathrm{bc}$ \\
T5 & $1.3 \mathrm{c}$ & $6.7 \mathrm{c}$ \\
T6 & $0.8 \mathrm{bc}$ & $3.6 \mathrm{bd}$ \\
\hline
\end{tabular}

Statistical analysis between values with different letters are statistically significant $(p<0.05)$

There was a noticeable increase in the exchangeable sodium percentage in all cases studied; although it remained below the $7 \%$ limit recommended by Pizaro (1990). However, just as for the SAR, one must be careful about the use of treated effluent for periods of time longer than this study.

\subsection{Crop Yield}

Table 5 shows the means values obtained for the rosebushes productivity, in each test, during the experiment. An increase in the production of commercial stems was observed when using the anaerobic and the nitrified effluents. The means were significantly higher than those obtained for the use of clean water, even when they were fertilized. The use of nitrified effluent without fertilization caused a productivity increase of $31.8 \%$. These data differ from those presented by Nirit et al. (2006) who saw no difference in productivity

Table 5 Means observed for the productivity of cultivated flowers

\begin{tabular}{ll}
\hline Test & Number of commercial stems \\
\hline T1 & $230 \mathrm{a}$ \\
T2 & $324 \mathrm{~b}$ \\
T3 & $317 \mathrm{~b}$ \\
T4 & $329 \mathrm{~b}$ \\
T5 & $359 \mathrm{~b}$ \\
T6 & $245 \mathrm{a}$ \\
\hline
\end{tabular}

Statistical analysis between values with different letters are statistically significant $(p<0.05)$ with rosebushes irrigated with treated effluent and drinking water.

According to Smirnoff and Stewart (1985), the Rosaceae species are experts in the use of nitrogen as nitrate form. There was a predominance of this form of nitrogen in the effluent from the sand filters; however, no significant difference was found with the use of the anaerobic effluent, which contains it in the organic and ammoniacal forms. In turn, Feigin et al. (1986) suggest that the optimal ratio between $\mathrm{NH}_{4}{ }^{+}: \mathrm{NO}_{3}{ }^{-}$is equal to 25:75\% for rosebush cultivation, there is a higher productivity when compared to fertilization with $100 \%$ nitrate. In this study, the anaerobic and nitrified effluents showed the proportion of $\mathrm{NH}_{4}{ }^{+}: \mathrm{NO}_{3}{ }^{-}$equal to $98: 2 \%$ and $14: 86 \%$ respectively, with no statistically significant difference between tests in which there was a predominance of each of these compounds (T2 to T5). Cabrera (2001) while employing different proportions of $\mathrm{NH}_{4}{ }^{+}: \mathrm{NO}_{3}{ }^{-}$in the cultivation of potted roses also found no difference in productivity after 13 months of production.

Another factor influencing the productivity of plants is potassium. Potassium was added to the influent of sand filters in the form of potassium carbonate to serve as a buffer. This action sought to maintain an appropriate $\mathrm{pH}$ for nitrification process that occurred in the sand filter. According to Woodson and Boodley (1982) under high potassium concentration, roses absorb most of the nitrogen in the ammonium form instead of nitrogen as nitrate. As shown in Table 2, the nitrified effluent from the sand filter possessed predominantly nitrogen as nitrate. Thus, high concentrations of potassium can be prevented better yield compared to that obtained with the anaerobic effluent irrigation.

\subsection{Evaluation of Floral Buds and Stems}

Table 6 shows no significant statistical difference between the lengths and diameters of the flower buds. Table 7 shows significant difference, in the rose stems, only between the test using the supply water with topdressing (T6), and those with nitrified (T2) and anaerobic (T3) effluent combined with the same topdressing. In turn, the test employing clean water with topdressing (T6) produced stems with average diameters with no significant difference compared to the ones irrigated with anaerobic (T4) and nitrified (T5) effluents, both without topdressing. One explanation is the 
Table 6 Diameter and length of the flower buds

Statistical analysis between values with different letters are statistically significant $(p<0.05)$

\begin{tabular}{|c|c|c|c|c|c|c|}
\hline & $\mathrm{T} 1$ & $\mathrm{~T} 2$ & $\mathrm{~T} 3$ & $\mathrm{~T} 4$ & $\mathrm{~T} 5$ & T6 \\
\hline \multicolumn{7}{|c|}{ Diameter of the flower buds $(\mathrm{cm})$} \\
\hline Means & $3.3 \pm 0.5 \mathrm{a}$ & $3.2 \pm 0.5 \mathrm{a}$ & $3.2 \pm 0.5 \mathrm{a}$ & $3.3 \pm 0.5 \mathrm{a}$ & $3.2 \pm 0.6 \mathrm{a}$ & $3.4 \pm 0.5 \mathrm{a}$ \\
\hline Maximum & 5.0 & 5.5 & 5.6 & 5.3 & 6.8 & 5.2 \\
\hline Minimum & 1.0 & 2.0 & 2.0 & 2.1 & 2.2 & 2.1 \\
\hline \multicolumn{7}{|c|}{ Bud length (cm) } \\
\hline Means & $4.6 \pm 0.5 \mathrm{a}$ & $4.5 \pm 0.5 \mathrm{a}$ & $4.4 \pm 0.5 \mathrm{a}$ & $4.5 \pm 0.5 \mathrm{a}$ & $4.6 \pm 0.6 \mathrm{a}$ & $4.6 \pm 0.6 \mathrm{a}$ \\
\hline Maximum & 6.0 & 5.8 & 5.9 & 5.9 & 6.1 & 6.2 \\
\hline Minimum & 3.0 & 2.4 & 2.4 & 3.0 & 3.0 & 2.7 \\
\hline$N$ & 245 & 323 & 317 & 329 & 350 & 230 \\
\hline
\end{tabular}

possible over fertilization of T2 and T3 tests, which according to Chow et al. (2009) does not increase productivity, and causes the proliferation of pests on crops.

According to Casarini (2000), stems with diameters equal or greater than $0.60 \mathrm{~cm}$ have higher quality and durability after the harvest; thus, increasing its acceptance by the consumer market, and acquiring better prices for the product. Table 7 shows the highest rates of diameters equal or greater than $0.60 \mathrm{~cm}$ for the test irrigated with the supply water indicating a slight loss in quality when irrigated with the anaerobic or nitrified effluents. The use of anaerobic effluent with topdressing provided the worst results. However, it is noteworthy that there was no significant difference between the tests. These results confirm the experiment conducted by Casarini (2004), who used only clean water and conventional fertilization through a fertigation system, and noticed a reduction in stem diameter with the increasing doses of nitrogen.

The stem size is another important factor for the marketing of roses; at the producing farms, wrapping units are separated by the following lengths: 30,40 , and $60 \mathrm{~cm}$. The $30 \mathrm{~cm}$ stems are classified as short, the $40 \mathrm{~cm}$ as medium, and the $60 \mathrm{~cm}$ as long stems, which carries the highest value for commercialization. In this study, no significant difference was found in the rate of the length of the rose stems for the different tests. This confirms the studies carried out in Israel, where Nirit et al. (2006) cultivated rosebushes and found no differences with the use of treated effluent, and drinking water for the irrigation. Likewise, Chow et al. (2009) found no statistical differences in the length of the rose stems fertilized with $10 \%$ of the recommended content of nitrogen, phosphorus, and potassium in the mineral form.

Table 7 Characteristics of the stems produced

\begin{tabular}{|c|c|c|c|c|c|c|}
\hline & $\mathrm{T} 1$ & $\mathrm{~T} 2$ & $\mathrm{~T} 3$ & $\mathrm{~T} 4$ & T5 & T6 \\
\hline \multicolumn{7}{|c|}{ Stem diameter $(\mathrm{cm})$} \\
\hline Means & $0.52 \pm 0.14 \mathrm{ab}$ & $0.51 \pm 0.12 \mathrm{a}$ & $0.50 \pm 0.09 \mathrm{a}$ & $0.51 \pm 0.12 \mathrm{ab}$ & $0.51 \pm 0.10 \mathrm{ab}$ & $0.53 \pm 0.12 \mathrm{~b}$ \\
\hline Maximum & 0.90 & 1.20 & 0.80 & 1.00 & 0.90 & 1.00 \\
\hline Minimum & 0.30 & 0.30 & 0.30 & 0.20 & 0.30 & 0.30 \\
\hline \multicolumn{7}{|c|}{ Rates of stem diameters greater than or equal to $0.60 \mathrm{~cm} \mathrm{( \% )}$} \\
\hline & $38 \mathrm{a}$ & $28 \mathrm{~b}$ & $21 \mathrm{c}$ & $26 \mathrm{~b}$ & $27 \mathrm{~b}$ & 33 a \\
\hline \multicolumn{7}{|c|}{ Rates of the stems sizes (\%) } \\
\hline $30 \mathrm{~cm}$ & $40 \mathrm{a}$ & $42 \mathrm{a}$ & $40 \mathrm{a}$ & $44 \mathrm{a}$ & $43 \mathrm{a}$ & $44 \mathrm{a}$ \\
\hline $40 \mathrm{~cm}$ & $53 \mathrm{a}$ & $49 \mathrm{a}$ & $53 \mathrm{a}$ & $50 \mathrm{a}$ & $49 \mathrm{a}$ & $45 \mathrm{a}$ \\
\hline $60 \mathrm{~cm}$ & $7 \mathrm{a}$ & $9 \mathrm{a}$ & $7 \mathrm{a}$ & $6 \mathrm{a}$ & $8 \mathrm{a}$ & $10 \mathrm{a}$ \\
\hline$N$ & 245 & 324 & 317 & 329 & 350 & 230 \\
\hline
\end{tabular}

Statistical analysis between values with different letters are statistically significant $(p<0.05)$ 


\section{Conclusions}

The production of marketable rose stems was higher in the tests using nitrified and anaerobic effluent than those using either fertilized or unfertilized water. The use of nitrified effluent expanded the production by $31.8 \%$.

The gain in productivity can also be coupled with the economic gain; since there was no significant difference between the use of treated effluents and the use of topdressing, which can lead to a reduction in the mineral fertilizers spending. However, care must be taken to the use of these effluents for long periods of time, because of possible soil salinity problems.

Acknowledgments This study was supported by São Paulo Research Foundation (FAPESP).

Open Access This article is distributed under the terms of the Creative Commons Attribution License which permits any use, distribution, and reproduction in any medium, provided the original author(s) and the source are credited.

\section{References}

Al-lahham, O., El assi, N. M., \& Fayyad, M. (2003). Impact of treated wastewater irrigation on quality attributes and contamination of tomato fruit. Agricultural Water Management Journal, 61(1), 51-62.

APHA, AWWA, WEF (2005). Standard methods for the examination of water and wastewater. 21 th ed. Washington DC, USA.

Ayres, R. S., Westcot, D. W. (2008) Water quality for agriculture. FAO Irrigation and Drainage Paper No 29 FAO, Rome, Italy.

Casarini, E. (2000). Manejo da irrigação na cultura da roseira cultivada em ambiente protegido. Escola Superior de Agricultura Luiz de Queiroz. Piracicaba, SP: Univ. São Paulo.

Casarini, E. (2004). Doses de N e K aplicados via fertirrigação na cultura da roseira (Rosa sp.) em ambiente protegido. Piracicaba, SP: Escola Superior de Agricultura Luiz de Queiroz, Univ. São Paulo.

Cabrera, R. I. (2001). Effect of $\mathrm{NaCl}$ salinity and nitrogen fertilizer formulation on yield and nutrient status of roses. Acta Horticulturae, 547, 255-260.

Cararo, D. C., Botrel, T. A., Hills, D. J., \& Leverenz, H. L. (2006). Analysis of clogging in drip emitters during wastewater irrigation. Applied Engineering in Agriculture, 22, 251-257.

Carr, R.M., Blumenthal, U.J., Mara, D.D. (2004) Health guidelines for the use of wastewater in agriculture: Developing realistic guidelines. Wastewater Use in Irrigated Agriculture Confronting the Livelihood and Environmental Realities.

Chow, A., Chau, A., \& Heinz, K. M. (2009). Reducing fertilization for cut roses: effect on crop productivity and twospotted spider mite abundance, distribution, and management. Journal of Economic Entomology, 102(5), 1896-1907.

Coppola, A., Santini, A., Botti, P., Vacca, S., Comegna, V., \& Severino, G. (2004). Methodological approach for evaluating the response of soil hydrological behavior to irrigation with treated municipal wastewater. Journal of Hydrology, 292(14), 114-34.

Crook, J. (1991). Quality criteria for reclaimed water. Water Science and Technology, 24(9), 109-121.

De Paula, A. M., Da Fonseca, A. F., Cardoso, E. J. B. N., \& Melfi, A. J. (2010). Microbial metabolic potential affected by surplus wastewater irrigation in tropical soil cultivated with Tifton 85 Bermuda grass (Cynodon dactylon Pers. X C. niemfuensis Vanderyst). Water, Air, and Soil Pollution, 205, 161-171.

Feigin, A., Ginzburg, C., Gileadi, S., \& Ackerman, A. (1986). Effect of $\mathrm{NH}_{4} / \mathrm{NO}_{3}$ ratio in nutrient solution on growth and yield of greenhouse roses. Acta Horticulturae, 189, 127-132.

Freitas, C. A. S., Silva, A. R. A., Bezerra, F. M. L., Andrade, R. R., Mota, F. S. B., \& Aquino, B. F. (2012). Growth of irrigated sunflower under different water sources and nitrogen fertilization. Revista Brasileira de Engenharia Agrícola e Ambiental, 16(10), 1031-1039.

Hassanli, A. M., Ebrahimizadeh, M. A., \& Beecham, S. (2009). The effects of irrigation methods with effluent and irrigation scheduling on water use efficiency and corn yield in arid region. Agricultural Water Management, 96(1), 93-99.

Lavee, D. (2010). A cost-benefit analysis of alternative wastewater treatment standards: a case study in Israel. Water and Environment Journal, 25(4), 504-512.

Lubello, C., Gori, R., Nicese, F. P., \& Ferrini, F. (2004). Municipaltreated wastewater reuse for plant nurseries irrigation. Water Research, 38(12), 2939-2947.

Monnet, F., Vaillant, N., Hitmi, A., Vernay, P., Coudret, A., \& Sallanon, H. (2002). Treatment of domestic wastewater using the nutrient film technique (NFT) to produce horticultura roses. Water Research, 36, 3489-3496.

Nirit, B., Asher, B. T., Haya, F., Pini, S., Ilona, R., Amram, C., \& Marina, I. (2006). Application of treated wastewater for cultivation of roses (Rosa hybrida) in soilless culture. Scientia Horticulturae, 108, 185-193.

Pizaro, F. (1990). Riegos localizados de alta frecuencia (2nd ed.). Madrid: Ediciones Mundi-Prensa.

Raij, B., Lopes, A. S., Casanova, E., \& Días-Zorita, M. (2008). Integrated nutrient management: experience from South America. In M. S. Aulakh \& C. A. Grant (Eds.), Integrated nutrient management for sustainable crop production (pp. 421-466). London: Haworth.

Rengasamy, P., \& Olsson, K. A. (1991). Sodicity and soil structure. Australian Journal of Soil Research, 29, 935-952.

Smirnoff, N., \& Stewart, G. R. (1985). Nitrate assimilation and translocation by higher plants: comparative physiology and ecological consequences. Physiologia Plantarum, 64, 133-140.

Tonetti, A. L., Coraucci Filho, B., Bertoncini, E. I., Oliveira, R. A., \& Stefanutti, R. (2010). Avaliação de um sistema simplificado de tratamento de esgotos visando a utilização em áreas rurais. Revista Brasileira de Engenharia Agrícola e Ambiental, 14(2), 227-234.

Woodson, W. R., \& Boodley, J. W. (1982). Effects of nitrogen form and potassium concentration on growth, flowering and nitrogen utilization of greenhouse roses. Journal of American Society of Science, 107(2), 275-278. 